\title{
Alcohol consumption and risk of fatty liver disease: a meta- analysis
}

\author{
Guoli Cao ${ }^{1}$, Tingzhuang Yi ${ }^{1,2}$, Qianqian Liu ${ }^{1}$, Min Wang ${ }^{1}$, Shaohui Tang ${ }^{\text {Corresp. } 1}$ \\ ${ }^{1}$ Department of Gastroenterology, The First Affiliated Hospital, Jinan University, Guangzhou, Guangdong, China \\ 2 Department of Gastroenterology, Affiliated Hospital of Youjiang Medical University for Nationlities, BaiSe, GuangXi, China \\ Corresponding Author: Shaohui Tang \\ Email address: tangshaohui206@163.com
}

Background. Observational studies have shown inconsistent results regarding alcohol consumption and risk of fatty liver. We performed a meta-analysis of published literature to investigate the association between alcohol consumption and fatty liver disease (FLD).

Methods. We searched Medline, Embase, Web of Science, and several Chinese databases, identifying studies that reported an association between alcohol consumption and the risk of FLD.

Results. A total of 16 studies with 76608 participants including 13 cross-sectional studies, 2 crosssectional following longitudinal studies, and 1 cohort study met the inclusion criteria. For light to moderate alcohol consumption (LMAC), there was a $22.6 \%$ reduction in risk of FLD (odds ratio [OR] $=0.774,95 \%$ confidence interval $[\mathrm{Cl}]: 0.695-0.862, P<0.001)$, and subgroup analysis showed that a greater reduction in risk of FLD was found in the female drinkers (30.2\%) and the drinkers with BMI $\geq 25$ $\mathrm{kg} / \mathrm{m}^{2}(31.3 \%)$ compared with the male drinkers (22.6\%) and the drinkers with $\mathrm{BMI}<25 \mathrm{~kg} / \mathrm{m}^{2}(21.3 \%)$, respectively. For heavy alcohol consumption, there was no significant influence on risk of FLD $(\mathrm{OR}=0.869,95 \% \mathrm{Cl}: 0.553-1.364, P=0.541)$ in Japanese women, but there was a $33.7 \%$ reduction in risk of FLD $(\mathrm{OR}=0.663,95 \% \mathrm{Cl}: 0.574-0.765, P<0.001)$ in Japanese men and a significant increased risk of FLD $(\mathrm{OR}=1.785,95 \% \mathrm{Cl}: 1.064-2.996, P=0.028)$ in Germans.

Conclusion. LMAC is associated with a significant protective effect on FLD inthe studied population, especially in the women and obese population. However, the effect of heavy alcohol consumption on FLD has been unsettled due to limited studies and small sample sizes. 


\section{PeerJ}

\section{Manuscript to be reviewed}

\section{Alcohol consumption and risk of fatty liver disease:}

2 a meta-analysis

3 Guoli Cao ${ }^{1 *}$, Tingzhuang Yi ${ }^{1,2 *}$, Qianqian Liu ${ }^{1 *}$, Min Wang ${ }^{1}$, Shaohui Tang ${ }^{1}$

4

$5 \quad{ }^{1}$ Department of Gastroenterology, The First Affiliated Hospital, Jinan University,

6 Guangzhou, China.

$7 \quad$ 2Department of Gastroenterology, Affiliated Hospital of Youjiang Medical University for

$8 \quad$ Nationlities, BaiSe, China.

$9 \quad$ *These authors contributed equally to this work.

11 Corresponding Author:

12 Shaohui Tang ${ }^{1}$

13 E-mail: tangshaohui206@163.com. 


\section{Manuscript to be reviewed}

\section{ABSTRACT}

2 Background. Observational studies have shown inconsistent results regarding

3 alcohol consumption and risk of fatty liver. We performed a meta-analysis of

4 published literature to investigate the association between alcohol consumption and

5 fatty liver disease (FLD).

6 Methods. We searched Medline, Embase, Web of Science, and several Chinese

7 databases, identifying studies that reported an association between alcohol

8 consumption and the risk of FLD.

9 Results. A total of 16 studies with 76608 participants including 13 cross-sectional studies, 2 cross-sectional following longitudinal studies, and 1 cohort study met the

11 inclusion criteria. For light to moderate alcohol consumption (LMAC), there was a $22.6 \%$ reduction in risk of FLD (odds ratio $[\mathrm{OR}]=0.774,95 \%$ confidence interval $[\mathrm{Cl}]$ : $0.695-0.862, P<0.001)$, and subgroup analysis showed that a greater reduction in risk

Keywords : Alcohol, Fatty liver disease, Risk, Meta-analysis. 


\section{Manuscript to be reviewed}

\section{INTRODUCTION}

2 Fatty liver disease (FLD) is caused by the excessive accumulation of fat in the liver cells (Nobili, Bedogni \& Tiribelli, 2014), which encompasses a morphological spectrum consisting of hepatic steatosis (fatty liver) and steatohepatitis that can progress to cirrhosis and hepatocellular carcinoma (Reddy \& Rao, 2006). FLD is commonly divided into alcoholic liver disease (ALD) and nonalcoholic fatty liver disease (NAFLD) (Reddy \& Rao, 2006).

ALD is a liver injury as a consequence of excessive or harmful alcohol use, which includes a spectrum of injury, ranging from simple steatosis to cirrhosis (O'Shea, Dasarathy \& McCullough, 2010; Torruellas, French \& Medici, 2014). NAFLD is defined as either the excessive fat accumulation or steatosis in the liver in patients who consume less than or equal to $30 \mathrm{~g}$ of alcohol per day for men and $20 \mathrm{~g}$ of alcohol per day for women after the exclusion of other causes such as hepatitis virus infection, use of steatogenic medication or hereditary disorders (Abd El-Kader \& El-Den Ashmawy, 2015). NAFLD has been considered to be the hepatic manifestation in the patients with metabolic syndrome (Angulo et al., 1999), but it may also occur in $29 \%$ of lean patients lacking associative risk factors (Bugianesi et al., 2005).

Although it has long been known that long-term heavy drinking is a cause of liver cirrhosis and liver cancer, the findings from recent observational studies have shown that light (Dunn, Xu \& Schwimmer, 2008; Nishioji et al., 2015), moderate (Moriya et al., 2013), and even heavier alcohol consumption (Gunji et al., 2009; Moriya et al., 2015) may decrease the risk of FLD. The mechanisms that explain the inverse association between alcohol consumption and FLD risk remain unknown, and the suggested mechanisms of protection by alcohol consumption include decreased 
1 insulin resistance, enhanced hepatic blood flow, antioxidant agents in alcoholic

2 beverages, decreased triglyceride content in the liver, and increased circulating

3 adiponectin (Moriya et al., 2013), Conversely, Lau et al.(Lau et al., 2015) indicated

4 that light alcohol consumption was associated with a higher prevalence of FLD;

5 Cotrim et al.(Cotrim et al., 2009) reported that light to moderate alcohol consumption

6 (LMAC) had no impact on the severity of activity and stage of FLD. Since the effect of

7 alcohol consumption on FLD development is still controversial, we therefore combined all published epidemiologic studies on this issue to evaluate the association between alcohol consumption and FLD risk.

11 MATERIALS AND METHODS

12 Search strategy

13 Guoli Cao and Tingzhuang Yi independently searched Medline, Embase, Web of 14 Science, and Chinese data sources including CNKI, Wanfang Data, and the VIP

PubMed search. English and Chinese language was used. Two independent reviewers made an initial judgment of whether the studies were eligible to be included in the meta-analysis, and any disagreements were resolved by consulting Shaohui

23 Tang.

\section{Inclusion and exclusion criteria}

The inclusion criteria required studies to: (1) have cross-sectional, case-control, 
1 cohort study or randomized controlled trial (RCT) design; (2) provide information on

2 alcohol consumption in relation to FLD, and the referent group are non-drinkers; (3)

3 report odds ratios (ORs) with their corresponding 95\% confidence intervals (Cls) or

4 original data allowing us to compute them; (4) diagnose populations with fatty liver

5 (hepatic steatosis) or steatohepatitis through the imaging, laboratory tests or liver

6 biopsy. Exclusion criteria included duplicate reports, abstracts, case reports, review

7 articles, editorials, and clinical guidelines.

\section{Data extraction}

10 Data extracted from each study included the name of the first author, study design, study region, study period, publication year, diagnostic method, the age and sex of subjects, sample size, adjustments, inclusion and exclusion criteria, average consumption of alcohol, the OR and their $95 \% \mathrm{Cl}$. All risk estimates are converted to published more than once, the results from the most recent one were selected.

\section{Definition of different alcohol consumption levels}

According to the recommendations of the World Health Organization (WHO, 2000), the average ethanol intake per drinking day can be usefully classified as "Low risk" ( $\leq 20 \mathrm{~g} /$ day for women and $\leq 40 \mathrm{~g} /$ day for men), "Medium risk" (>20-40 g/day for women and >40-60 g/day for men) and "High risk" (>40 g/day for women and >60 g/day for men. Based on the different levels of alcohol consumption reported in the 
1 included studies, we classified the drinkers into four groups: non-drinkers, persons

2 who drink $0 \mathrm{~g} /$ day of alcohol; light drinkers, persons who drink $\leq 20 \mathrm{~g} /$ day (or $\leq 140$

$3 \mathrm{~g} /$ week) of alcohol; moderate drinkers, persons who drink $>20-40 \mathrm{~g} /$ day (or $>140-280$

$4 \mathrm{~g} /$ week); and heavy drinkers, persons who drink>40 g/day (or>280 g/week).

5

6 Quality assessment

$7 \quad$ The quality of cross-sectional studies was assessed by the Agency for Healthcare

\section{Statistical analysis}

Statistical analysis was performed using STATA version 12.0 (Stata Corp, College

Station, Texas). The results were expressed in terms of OR and $95 \% \mathrm{Cl}$. Statistical heterogeneity was evaluated through the $Q$ test and $I^{2}$ statistic (Higgins \&

Thompson, 2002; Higgins et al., 2003), $P<0.05$ was considered statistically significant. The test statistic was distributed as $\chi^{2}$. $Q$ statistics was used to evaluate heterogeneity, with its $P$ values revealed by the forest plot. $I^{2}$ was used to estimate the size of the heterogeneity, with its $P$ values revealed by the forest plot. If the heterogeneity was acceptable $\left(I^{2}<50 \%\right)$, a fixed-effects model was conducted to calculate the pooled OR. Conversely, a random-effects model was used. The causes of heterogeneity were investigated by subgroup analysis. To evaluate whether the 
1 pooled results might be influenced by individual studies, a sensitivity analysis was

2 performed by omitting one study each time and recalculating the pooled OR. We applied Egger's test and Begg's method to assess bias. A two-sided $P$ value of less than 0.05 was regarded as significant.

\section{RESULTS}

7 Search results and study characteristics

8 Figure 1 shows the process of selecting studies for the meta-analysis. The searches

9 yield 2847 studies from Chinese and English databases, and 2622 studies were excluded based on title. Among the remaining 225 studies, 202 were further excluded 
1 2015), 2 cross-sectional following longitudinal studies(Yamada et al., 2010; Moriya

2 et al., 2015) and 1 cohort study (Hashimoto et al., 2015). Of the studies, 10 were

3 conducted in Asia ( 9 in Japan(Gunji et al., 2009; Yamada et al., 2010; Hiramine et

4 al., 2011; Hamaguchi et al., 2012; Moriya et al., 2013; Hashimoto et al., 2015;

5 Moriya et al., 2015; Nishioji et al., 2015; Sogabe et al., 2015) and 1 in Hong

6 Kong(Wong et al., 2012)) and 6 in other countries ( 2 in the US,(Dunn, Xu \&

7 Schwimmerl., 2008; Dunn et al., 2012) 1 in Brazil,(Cotrim et al., 2009) 1 in

8 Argentina(Sookoian, Castaño \& Pirola., 2014) and 2 in Germany(Kächele et al.,

9 2015; Lau et al., 2015)). 12 studies provided adjusted risk estimate, and 4 studies

10 reported only crude data. 1 study (Moriya et al., 2011) was excluded because it was

11 duplicate study (Tables 1 and 2).

Study quality

Most of the cross-sectional studies had provided specific inclusion and exclusion criteria, source of information, and controlled confounding factors. But only a few studies obtained a follow-up (Yamada et al., 2010; Moriya et al., 2015) and explained how missing data were handled (Dunn , Xu \& Schwimmer, 2008; Moriya et al., 2013; Kächele et al., 2015; Lau et al., 2015; Moriya et al., 2015; Nishioji et al., 2015; Sogabe et al., 2015). Most of the studies (Dunn, Xu \& Schwimmer., 2008; Gunji et al., 2009; Hiramine et al., 2011; Hamaguchi et al., 2012; Wong et al., 2012; Moriya et al., 2013; Kächele et al., 2015; Lau et al., 2015; Nishioji et al., 2015; Sogabe et al., 2015; Yamada et al., 2010; Moriya et al., 2015) were evaluated as low risk of bias, 2 studies (Cotrim et al., 2009; Dunn et al., 2012) had moderate risk of bias, and 1 study (Sookoian, Castaño \& Pirola, 2014) had high risk of bias (Table 3). The quality of cohort study (Hashimoto et al., 2015) was full score 
1 of 9 , and a score $\geq 6$ stars is considered to be high quality.

2

3 Light to moderate drinkers (LM drinkers) vs non-drinkers $(P=0.969)$ and Begg's test $(P=0.753)$ of the 16 studies. 0.661-0.979; $P=0.03$ ) in random effect model (Fig. 3).

A meta-analysis was conducted with the data from the 16 heterogeneous studies $\left(I^{2}=\right.$ $79.3 \%, P<0.001$ ) with 31942 LM drinkers, showing the LMAC was associated with a $22.6 \%$ reduction in risk of FLD $(\mathrm{OR}=0.774,95 \% \mathrm{Cl}: 0.695-0.862, P<0.001)$ using random effect model (Fig. 2). Subsequently, we conducted a sensitivity analysis by omitting one study each time and recalculating the pooled $\mathrm{OR}$, and the results showed that the pooled risk estimates did not change significantly. There was a symmetric funnel plot and no evidence of significant publication bias from Egger's test

Then, when a stratified analysis was conducted according to different amounts of alcohol consumption, a total of 15 heterogeneous studies(Dunn, Xu \& Schwimmer, 2008; Cotrim et al., 2009; Gunji et al., 2009; O'Shea, Dasarathy \& McCullough, 2010; Yamada et al., 2010; Hiramine et al., 2011; Dunn et al., 2012; Hamaguchi et al., 2012; Wong et al., 2012; Moriya et al., 2013; Hashimoto et al., 2015; Kächele et al., 2015; Lau et al., 2015; Moriya et al., 2015; Nishioji et al., 2015; Sogabe et al., 2015) were included in light alcohol consumption group $\left(I^{2}=66 \% ; P<0.001\right)$, and 8 heterogeneous studies(Cotrim et al., 2009; Gunji et al., 2009; Yamada et al., 2010; Hamaguchi et al., 2012; Hashimoto et al., 2015; Kächele et al., 2015; Lau et al., 2015; Moriya et al., 2015) in moderate alcohol consumption group $\left(I^{2}=82.7 \%\right.$; $P<0.001)$. The combined analysis showed a greater reduction $(25.3 \%)$ in risk of FLD in light alcohol consumption group (OR=0.747; 95\%Cl, 0.673-0.830; $P<0.001)$ compared with moderate alcohol consumption group $(19.6 \%)(\mathrm{OR}=0.804 ; 95 \% \mathrm{Cl}$, 


\section{Manuscript to be reviewed}

$1 \quad$ Further, a subgroup analysis was conducted by sex. In women, the result showed

2 that LMAC was associated with a $30.2 \%$ reduction in risk of FLD $(\mathrm{OR}=0.698,95 \% \mathrm{Cl}$ :

$3 \quad 0.628-0.776, P<0.001$ ) using the 7 studies with 5955 LM drinkers (Yamada et al.,

4 2010; Hamaguchi et al., 2012; Moriya et al., 2013; Hashimoto et al., 2015; Lau et

5 al., 2015; Moriya et al., 2015; Nishioji et al., 2015) without significant heterogeneity

$6 \quad\left(I^{2}=0.0 \%, P=0.571\right)$ with fixed effect model. In men, the 9 heterogeneous studies

7 (Gunji et al., 2009; Yamada et al., 2010; Hiramine et al., 2011; Hamaguchi et al.,

2012; Hashimoto et al., 2015; Lau et al., 2015; Moriya et al., 2015; Nishioji et al., 2015; Sogabe et al., 2015) ( $\left.I^{2}=90.2 \%, P<0.001\right)$ with 19858 LM drinkers were included in the analysis, only showing a $22.6 \%$ reduction in risk of FLD $(O R=0.774$, $95 \% \mathrm{Cl}: 0.657-0.913, P=0.002)$ in relation to the LMAC using random effect model (Fig. 4). Sensitive analysis indicated that no individual studies could change the pooled results in women and in men.

Finally, we also conducted another subgroup analysis by BMI (body mass index). In the groups with BMI $\geq 25 \mathrm{~kg} / \mathrm{m}^{2}$ and $<25 \mathrm{~kg} / \mathrm{m}^{2}$ for subjects, there were 8 heterogeneous $\left(I^{2}=82.0 \% \%, P<0.001\right)$ (Dunn, Xu \& Schwimmer, 2008; Cotrim et al., 2009; Dunn et al., 2012; Sookoian, Castaño \& Pirola., 2014; Kächele et al., 2015; Lau et al., 2015; Nishioji et al., 2015; Sogabe et al., 2015) and 9 heterogeneous $\left(I^{2}=70.8 \% \%, P<0.001\right)(G u n j i$ et al., 2009; Yamada et al., 2010; Hiramine et al., 2011; Hamaguchi et al., 2012; Wong et al., 2012; Moriya et al., 2013; Hashimoto et al., 2015; Moriya et al., 2015; Nishioji et al., 2015) studies were included, respectively. The combined results showed a greater protective effect of LMAC on FLD development in the drinkers with $\mathrm{BMI} \geq 25 \mathrm{~kg} / \mathrm{m}^{2}(\mathrm{OR}=0.687,95 \% \mathrm{Cl}$ : 0.508-0.930, $P=0.015)$ compared with the drinkers with $\mathrm{BMl}<25 \mathrm{~kg} / \mathrm{m}^{2}(\mathrm{OR}=0.787$, 95\% Cl: 0.715-0.866, $P<0.001)$ using random effect model (Fig. 5). 


\section{Manuscript to be reviewed}

2 Heavy drinkers vs non-drinkers

3 Significant heterogeneity was found among the 8 studies (6 conducted in Japan and 2

4 in Germany) with 5468 heavy drinkers(Gunji et al., 2009; Yamada et al., 2010;

$5 \quad$ Hiramine et al., 2011; Hamaguchi et al., 2012; Hashimoto et al., 2015; Kächele et al., 2015; Lau et al., 2015; Moriya et al., 2015) $\left(I^{2}=93.6 \%, P<0.001\right)$, and there was 
1 with decreased heterogeneity $\left(I^{2}=61.6 \%, P=0.023\right)$ using random effect model (Fig.

2 7). In the group B, 132 heavy drinkers and 213 male heavy drinkers were included by

3 Kächele et al. (Kächele et al., 2015) and Lau et al. (Lau et al., 2015), respectively,

4 and an increased risk of FLD was observed in relation to heavy alcohol consumption

$5(\mathrm{OR}=1.785,95 \% \mathrm{Cl}: 1.064-2.996, P=0.028)$ with decreased heterogeneity $\left(I^{2}=69.9 \%\right.$,

$6 \quad P=0.068$ ) using random effect model (Fig. 6).

\section{DISCUSSION}

9 Alcohol consumption is a common lifestyle factor and has been associated with 
1 heterogeneous studies $\left(I^{2}=79.3 \%\right)$ with 31942 LM drinkers, we revealed that LMAC

2 was associated with a $22.6 \%$ reduction in risk of FLD. The finding was similar to a

3 previous meta-analysis only including 10 heterogeneous studies by Sookoian et al.

4 (Sookoian, Castaño \& Pirola, 2014), who found that light or modest drinkers (less

5 than $40 \mathrm{~g} /$ day of alcohol) had a $31.2 \%$ reduction in risk of NAFLD compared with

6 nondrinkers. Then, we conducted an amount-stratified analysis with respect to LMAC.

7 The drinkers were classified into light ( $\leq 20 \mathrm{~g} /$ day) and moderate (>20-40 g/day)

8 drinkers. The result indicated that a greater protective role for FLD was found in the

9 light drinkers (25.3\%) compared with the moderate drinkers (19.6\%). Further, we

10 want to know if the beneficial effect is influenced by sex and BMI. Our result showed that the protective effect of LMAC on FLD seemed to be greater in the female drinkers $(30.2 \%)$ and the drinkers with $\mathrm{BMI} \geq 25 \mathrm{~kg} / \mathrm{m}^{2}(31.3 \%)$ compared with the male drinkers (22.6\%) and the drinkers with $\mathrm{BMI}<25 \mathrm{~kg} / \mathrm{m}^{2}(21.3 \%)$, respectively.

Consistent with our findings, Sookoian et al. also showed that the protective effect of light or modest alcohol consumption on NAFLD was significantly higher in women population.

In the meta-analysis of heavy drinkers vs nondrinkers, the 8 heterogeneous studies $\left(I^{2}=93.6 \%\right)(6$ conducted in Japan and 2 in Germany) with 5468 heavy drinkers were included. The pooled OR showed that heavy alcohol consumption was not statistically 
1 associated with risk of FLD. Then, the above 8 studies were divided into two groups

2 according to study areas. The pooled result from the 6 Japanese studies showed a

$33.2 \%$ reduction in risk of FLD in relation to heavy alcohol consumption. Further subgroup analysis by sex indicated that heavy alcohol consumption had no significant influence on risk of FLD in Japanese women, but yielded a $33.7 \%$ reduction in risk of FLD in Japanese men. However, in the meta-analysis from the 2 Germanic studies that included 132 heavy drinkers and 213 male heavy drinkers, an increased risk of FLD was found in relation to heavy alcohol consumption. Concordant with our results from Japanese studies, Knott et al. reported that reductions in the risk of type 2 diabetes were present at all levels of alcohol intake $<63$ g/day (Knott, Bell \& Britton., 2015); Larsson et al. noted that high alcohol consumption ( $\geq 14$ drinks/week) did not increase risk of heart failure (Larsson, Orsini \& Wolk, 2015). However, because of the limited studies and small sample sizes, the effect of heavy alcohol consumption on FLD remains to be settled, and more prospective studies are needed.

The causal impact of alcohol on liver cirrhosis has long been known. But the likelihood of developing progressive alcohol-induced liver disease or cirrhosis is not completely dose-dependent, because it occurs in only a subset of patients (O'Shea, Dasarathy \& McCullough, 2010). Bellentani et al. reported that, in a population-based cohort study of almost 7000 subjects in Italy, even among subjects with very high daily alcohol intake (120 g/day), only $13.5 \%$ developed ALD (Saccoccio et al., 1997), which means that heavy alcohol consumption is likely not to increase risk of liver disease in most of the subjects. It has been shown that the development and progression of alcohol-associated liver disease may depend upon multiple risk factors, including the dose, duration, and type of alcohol consumption, drinking patterns, sex, ethnicity, and genetic factors, and so on (O'Shea, Dasarathy 


\section{Manuscript to be reviewed}

1 \& McCullough, 2010).

In the two previous meta-analysis conducted by Corrao et al. and Rehm et al., they included 15 and 17 epidemiological studies, respectively, mainly from the USA and Europe, and assessed the association between alcohol consumption and liver cirrhosis, demonstrating that heavy alcohol consumption significantly increases risk of liver cirrhosis (Corrao et al., 1998; Rehm et al., 2010). Corrao et al. also found that the same amount of average alcohol consumption was related to a higher risk of liver cirrhosis in women than in men. In the present meta-analysis, we evaluated the association of alcohol consumption with risk of FLD by including the 16 observational studies mainly from Asia, especially Japan. Our results, which have been described above, are inconsistent with the findings in the two previous meta-analysis. The different results between our study and the two previous meta-analysis may be explained in part by the differences in different stages of FLD development, and ethnicity and genetic factors. The two meta-analysis by Corrao et al. and Rehm et al. assessed the association of alcohol consumption with frank liver cirrhosis, namely end-stage liver disease of ALD development, whereas our meta-analysis evaluated the correlation between alcohol consumption and risk of the relative early stages of ALD development, namely fatty liver (simple steatosis) and steatohepatitis. On the other hand, Kwon et al. reported that aldehyde dehydrogenase 2 (ALDH2) deficiency can ameliorate alcoholic fatty liver in mice (Kwon et al., 2014). Approximately $40-50 \%$ of East Asians carry an inactive ALDH2 gene (ALDH2*2 allele) (Singh et al., 1989), but it is very rarely that ALDH2*2 allele is found in European (Peterson, Goldman \& Long, 1999). The above data appear to partly explain the reason why even excessive alcohol consumption also seemed to have a protective effect on FLD in Japanese men. 
1 There were limitations to our meta-analysis that should be considered. The main

2 limitation of this study was a small number of included studies and subjects (only 16

3 studies and 76608 subjects), so further subgroup analysis were not able to be

4 perform according to type of alcoholic beverages, frequency of alcohol consumption,

5 duration of alcohol consumption, study region and age groups. Secondly, this

6 meta-analysis contained only 1 cohort study, and the remaining 15 were

7 cross-sectional studies that signify a low quality, because self-reported data on

8 alcohol consumption in epidemiological studies may not be reliable. Thirdly, in the 10

9 Asian studies included, 9 were from Japan and 1 was from Hong Kong, thus the study

10 coverage in Asian was limited because of absence of studies from other Asian

11 countries, especially Chinese Mainland. Moreover, just 6 studies from other countries

12 (USA, Brazil, Argentina and Germany) were included, thus the study coverage in the world was limited because of absence of studies from Africa and Australia, and a small number of the studies from the USA and Europe. Therefore, the value of our or Egger's test. results is limited for other areas except the countries involved in the study (such as China, Africa, Australia, most European countries, and so on). Fourthly, because FLD is a multi-factorial disease, it is uncertain whether other factors may have influenced the results. Fifthly, because early stages of ALD are often asymptomatic, and most of subjects in the included studies were asymptomatic from health check-up at hospital, therefore the results of meta-analysis from these studies can't be effectively broadened so as to represent the population at large. Lastly, potential publication bias might have influence the results, despite no bias indicated from either the funnel plot 
1 In summary, LMAC is associated with a significant protective effect on FLD in the

2 studied population, especially in the women and obese population. However, the

3 effect of heavy alcohol consumption on FLD has been unsettled due to limited studies

4 and small sample sizes.

5 However, because of the accepted involvement of alcohol consumption, especially excessive drinking in liver disease or cirrhosis, these findings should be treated with caution. Further better-prospective studies are needed to answer the question of whether alcohol consumption has a diverse effect on FLD in different areas, and whether different kinds of beverages or drinking patterns have a diverse

10 effect on FLD. 


\section{Manuscript to be reviewed}

1 REFERENCES

2 Abd El-Kader SM, El-Den Ashmawy EM. 2015. Non-alcoholic fatty liver

disease:The diagnosis and management. World Journal of Hepatology 7:846-858 DOI 10.4254/wjh.v7.i6.846.

Angulo P, Keach JC, Batts KP, Lindor KD. 1999. Independent predictors of liver fibrosis in patients with nonalcoholic steatohepatitis. Hepatology 30:1356-1362 DOI 10.1002/hep.510300604.

Bedogni G, Nobili V, Tiribelli C. 2014. Epidemiology of fatty liver: An update. World Journal of Gastroenterology 20:9050-9054 DOI 10.3748/wjg.v20.i27.9050.

\section{Bellentani S, Saccoccio G, Costa G, Tiribelli C, Manenti F, Sodde M, Saveria} Crocè L, Sasso F, Pozzato G, Cristianini G, Brandi G. 1997. Drinking habits as cofactors of risk for alcohol induced liver damage. Gut 41:845-850.

Bugianesi E, Gastaldelli A, Vanni E, Gambino R, Cassader M, Baldi S, Ponti V, Pagano G, Ferrannini E, Rizzetto M. 2005. Insulin resistance in non-diabetic patients with non-alcoholic fatty liver disease: sites and mechanisms. Diabetologia 48:634-642 DOI 10.1007/s00125-005-1682-x.

Corrao G, Bagnardi V, Zambon A, La Vecchia C. 2004. A meta-analysis of alcohol consumption and the risk of 15 diseases. Preventive Medicine 38:613-619 DOI 10.1016/j.ypmed.2003.11.027.

Corrao G, Bagnardi V, Zambon A, Torchio P. 1998. Meta-analysis of alcohol intake in relation to risk of liver cirrhosis. Alcohol and Alcoholism 33:381-392

Cotrim HP, Freitas LA, Alves E, Almeida A, May DS, Caldwell S. 2009. Effects of light-to-moderate alcohol consumption on steatosis and steatohepatitis in severely obese patients. European Journal of Gastroenterology and Hepatology 21:969-972 DOI 10.1097/MEG.0b013e328328f3ec. 


\section{Manuscript to be reviewed}

1 Dunn W, Sanyal AJ, Brunt EM, Unalp-Arida A, Donohue M, McCullough AJ,

Schwimmer JB. 2012. Modest alcohol consumption is associated with decreased prevalence of steatohepatitis in patients with non-alcoholic fatty liver disease (NAFLD). Journal of Hepatology 57:384-391 DOI

\subsection{6/j.jhep.2012.03.024.}

Dunn W, Xu R, Schwimmer JB. 2008. Modest wine drinking and decreased prevalence of suspected nonalcoholic fatty liver disease. Hepatology 47:1947-1954 DOI 10.1002/hep.22292.

Gong Y, Feng K, Yan N, Xu Y, Pan CW. 2015. Different amounts of alcohol consumption and cataract: a meta-analysis. Optometry and Vision Science 92:471-479 DOI 10.1097 / OPX.0000000000000558.

Gunji T, Matsuhashi N, Sato H, Fujibayashi K, Okumura M, Sasabe N, Urabe A. 2009. Light and moderate alcohol consumption significantly reduces the prevalence of fatty liver in the Japanese male population. American Journal of Gastroenterology 104:2189-2195 DOI 10.1038/ajg.2009.361.

Hamaguchi M, Kojima T, Ohbora A, Takeda N, Fukui M, Kato T. 2012. Protective effect of alcohol consumption for fatty liver but not metabolic syndrome. World Journal of Gastroenterology 18:156-167 DOI 10.3748/wjg.v18.i2.156.

Hashimoto Y, Hamaguchi M, Kojima T, Ohshima Y, Ohbora A, Kato T, Nakamura N, Fukui M. 2015. The modest alcohol consumption reduces the incidence of fatty liver in men: a population-based large-scale cohort study. Journal of Gastroenterology and Hepatology 30:546-552 DOI 10.1111/jgh.12786.

Higgins JP, Thompson SG. 2002. Quantifying heterogeneity in a meta-analysis. Statistics in Medicine 21:1539-1558.

Higgins JP, Thompson SG, Deeks JJ, Altman DG. 2003. Measuring inconsistency 
in meta-analyses. British Medical Journal 327:557-560.

2 Hiramine Y, Imamura Y, Uto H, Koriyama C, Horiuchi M, Oketani M, Hosoyamada

K, Kusano K, Ido A, Tsubouchi H. 2011. Alcohol drinking patterns and the risk of fatty liver in Japanese men. Journal of Gastroenterology 46:519-528 DOI 10.1007/s00535-010-0336-z.

Kächele M, Wolff S, Kratzer W, Haenle M, Homann J, Trischler G, Koenig W, Imhof A. 2015. Presence of fatty liver and the relationship between alcohol consumption and markers of inflammation. Mediators of Inflammation 2015:278785 DOI 10.1155/2015/278785.

Knott C, Bell S, Britton A. 2015. Alcohol Consumption and the Risk of Type 2 Diabetes: A Systematic Review and Dose-Response Meta-analysis ofMore Than 1.9 Million Individua. Diabetes Care 38:1804-1812 DOI

10.2337/dc15-0710/-/DC1.

Koppes LL, Dekker JM, Hendriks HF, Bouter LM, Heine RJ. 2005. Moderate alcohol consumption lowers the risk of type 2 diabetes: a meta-analysis of prospective observational studies. Diabetes Care 28:719-725.

Kwon HJ, Won YS, Park O, Chang B, Duryee MJ, Thiele GE, Matsumoto A, Singh S, Abdelmegeed MA, Song BJ, Kawamoto T, Vasiliou V, Thiele GM, Gao B. 2014. Aldehyde dehydrogenase 2 deficiency ameliorates alcoholic fatty liver but worsens liver inflammation and fibrosis in mice. Hepatology 60:146-157 DOI 10.1002/hep.27036.

Larsson SC, Orsini N, Wolk A. 2015. Alcohol consumption and risk of heart failure: a dose-response meta-analysis of prospective studies. European Journal of Heart failure 17:367-373 DOI 10.1002/ejhf.228.

Lau K, Baumeister SE, Lieb W, Meffert PJ, Lerch MM, Mayerle J, Völzke H. 2015. 


\section{Manuscript to be reviewed}

The combined effects of alcohol consumption and body mass index on hepatic steatosis in a general population sample of European men and women. Alimentary pharmacology and Therapeutics 41:467-476 DOI 10.1111/apt.13067.

Moriya A, Iwasaki Y, Ohguchi S, Kayashima E, Mitsumune T, Ikeda F, Ando M, Yamamoto K. 2013. Roles of alcohol drinking pattern in fatty liver in Japanese women. Hepatology International 7:859-868 DOI 10.1007/s12072-013-9449-9.

Moriya A, Iwasaki Y, Ohguchi S, Kayashima E, Mitsumune T, Taniguchi H, Ikeda F, Shiratori Y, Yamamoto K. 2011. Alcohol consumption appears to protect against non-alcoholic fatty liver disease. Alimentary Pharmacology and Therapeutics 33:378-388 DOI 10.1111/j.1365-2036.2010.04520.x.

Moriya A, Iwasaki Y, Ohguchi S, Kayashima E, Mitsumune T, Taniguchi H, Ando M, Yamamoto K. 2015. Roles of alcohol consumption in fatty liver: A longitudinal study. Journal of hepatology 62:921-927 DOI 10.1016/j.jhep.2014.11.025.

Nishioji K, Sumida Y, Kamaguchi M, Mochizuki N, Kobayashi M, Nishimura T, Yamaguchi K, Itoh Y. 2015. Prevalence of and risk factors for non-alcoholic fatty liver disease in a non-obese Japanese population, 2011-2012. Journal of Gastroenterology 50:95-108 DOI 10.1007/s00535-014-0948-9.

O'Shea RS, Dasarathy S, McCullough AJ. 2010. Alcoholic liver disease. Hepatology 51:307-328 DOI 10.1002/hep.23258.

Peterson RJ, Goldman D, Long JC. 1999. Effects of worldwide population subdivision on ALDH2 linkage disequilibrium. Genome Research 9:844-852

Reddy JK, Rao MS. 2006. Lipid metabolism and liver inflammation. II. Fatty liver disease and fatty acid oxidation. American Journal of Physiology-Gastrointestinal and Liver Physiology 290:G852-G858 DOI 10.1152/ajpgi.00521.2005.

Rehm J, Room R, Graham K, Monteiro M, Gmel G, Sempos CT. 2003. The 


\section{Manuscript to be reviewed}

relationship of average volume of alcohol consumption and patterns of drinking to burden of disease: an overview. Addiction 98:1209-1228

Rehm J, Taylor B, Mohapatra S, Irving H, Baliunas D, Patra J, Roerecke M. 2010. Alcohol as a risk factor for liver cirrhosis: a systematic review and meta-analysis. Drug and Alcohol Review 29:437-445 DOI 10.1111/j.1465-3362.2009.00153.x.

Rimm EB, Williams P, Fosher K, Criqui M, Stampfer MJ. 1999. Moderate alcohol intake and lower risk of coronary heart disease: meta-analysis of effects on lipids and haemostatic factors. British Medical Journal 319:1523-1528

Ronksley PE, Brien SE, Turner BJ, Mukamal KJ, Ghali WA. 2011. Association of alcohol consumption with selected cardiovascular disease outcomes:a systematic review and meta-analysis. British Medical Journal 342:1-13 DOI 10.1136/bmj.d671.

Rostom A, Dube C, Cranney A, Saloojee N, Sy R, Garritty C, Sampson M, Zhang L, Yazdi F, Mamaladze V, Pan I, McNeil J, Moher D, Mack D, Patel D. 2004. Celiac Disease. Evidence Reports/Technology Assessments,No.104. Rockville (MD): Agency for Healthcare Research and Quality (US). Available from: http://www.ncbi.nlm.nih.gov/books/NBK35156 (Accessed 15 April 2016).

Singh S, Fritze G, Fang BL, Harada S, Paik YK, Eckey R, Agarwal DP, Goedde HW. 1989. Inheritance of mitochondrial aldehyde dehydrogenase: genotyping in Chinese, Japanese and South Korean families reveals dominance of the mutant allele. Human Genetics 83:119-121

Sogabe M, Okahisa T, Taniguchi T, Tomonari T, Tanaka T, Tanaka H, Nakasono M, Takayama T. 2015. Light alcohol consumption plays a protective role against non-alcoholic fatty liver disease in Japanese men with metabolic syndrome. Liver International 35:1707-1714 DOI 10.1111/liv.12754. 


\section{Manuscript to be reviewed}

1 Sookoian S, Castaño GO, Pirola CJ. 2014. Modest alcohol consumption decreases the risk of non-alcoholic fatty liver disease: a meta-analysis of 43175 individuals. Gut 63:530-532 DOI 10.1136/gutjnl-2013-305718.

Torruellas C, French SW, Medici V. 2014. Diagnosis of alcoholic liver disease. World J Gastroenterology 20:11684-11699 DOI 10.3748/wjg.v20.i33.11684.

WHO. 2000. International Guide for Monitoring Alcohol Consumption and Related Harm. Geneva: World Health Organization

Wells GA, Shea B, O'Connell D, Peterson D, Welch V, Losos M, Tugwell P. 2011. The Newcastel-Ottawa Scale (NOS) for assessing the quality of nonrandomised studies in meta-analyses. Ottawa Hospital Research Institute. Available from: http://www.ohri.ca/programs/clinical_epidemiology/oxford.asp (Accessed 15 April 2016).

Wong VW, Chu WC, Wong GL, Chan RS, Chim AM, Ong A, Yeung DK, Yiu KK, Chu SH, Woo J, Chan FK, Chan HL. 2012. Prevalence of non-alcoholic fatty liver disease and advanced fibrosis in Hong Kong Chinese: a population study using proton-magnetic resonance spectroscopy and transient elastography. Gut 61:409-415 DOI 10.1136/gutjnl-2011-300342.

Yamada T, Fukatsu M, Suzuki S, Yoshida T, Tokudome S, Joh T. 2010. Alcohol Drinking May Not Be a Major Risk Factor for Fatty Liver in Japanese Undergoing a Health Checkup. Digestive Diseases and Sciences 55:176-182 DOI 10.1007/s10620-008-0693-0.

You M, Crabb DW. 2004. Recent advances in alcoholic liver disease II. Minireview:molecular mechanisms of alcoholic fatty liver. American Journal of Physiology-gastrointestinal and Liver Physiology 287:G1-G6 DOI 10.1152/ajpgi.00056.2004. 
Table 1. Characteristics of studies included in the meta-analysis.

\begin{tabular}{|c|c|c|c|c|c|c|c|}
\hline Study & Design & $\begin{array}{l}\text { Study } \\
\text { region }\end{array}$ & $\begin{array}{l}\text { Study } \\
\text { period }\end{array}$ & $\begin{array}{l}\text { Outcom } \\
\text { e }\end{array}$ & $\begin{array}{l}\text { Diagnostic } \\
\text { method }\end{array}$ & $\begin{array}{l}\text { BMI } \\
\text { (mean) }\end{array}$ & Age(years) \\
\hline $\begin{array}{l}\text { Dunn et al., } \\
2008\end{array}$ & Cross-section & $\begin{array}{l}\text { The } \\
\text { United } \\
\text { States }\end{array}$ & 1988-1994 & FLD & $\begin{array}{l}\text { Laboratory } \\
\text { examination }\end{array}$ & 26.99 & $>21$ \\
\hline $\begin{array}{l}\text { Cotrim et al., } \\
2009\end{array}$ & Cross-section & Brazil & $2004-2005$ & FLD & Biopsy & 43.9 & $37.27 \pm 11.06$ \\
\hline $\begin{array}{l}\text { Gunji et al., } \\
2009\end{array}$ & Cross-section & Japan & $2007-2008$ & FLD & Ultrasound & 23.5 & $50.9 \pm 8.1^{a}$ \\
\hline $\begin{array}{l}\text { Yamada et al., } \\
2010\end{array}$ & $\begin{array}{l}\text { Cross-sectional } \\
\text { and } \\
\text { longitudinal }\end{array}$ & Japan & $2000-2005$ & FLD & Ultrasound & 22.58 & $\begin{array}{l}49.8 \pm 10.7^{a} \\
50.4 \pm 9.3^{b}\end{array}$ \\
\hline $\begin{array}{l}\text { Hiramine et al., } \\
2011\end{array}$ & Cross-section & Japan & $2000-2007$ & FLD & Ultrasound & 23.7 & $30-69^{a}$ \\
\hline $\begin{array}{l}\text { Wong et al., } \\
2012\end{array}$ & Cross-section & HongKong & $2008-2010$ & FLD & Ultrasound & 22.8 & $48 \pm 11$ \\
\hline $\begin{array}{l}\text { Dunn et al., } \\
2012\end{array}$ & Cross-section & $\begin{array}{l}\text { The } \\
\text { United } \\
\text { States }\end{array}$ & - & FLD & Biopsy & 34.36 & $>21$ \\
\hline $\begin{array}{l}\text { Hamaguchi } \\
\text { et al.,2012 }\end{array}$ & Cross-section & Japan & 2004-2009 & FLD & Ultrasound & 22.57 & $18-88$ \\
\hline $\begin{array}{l}\text { Moriya et al., } \\
2013\end{array}$ & Cross-section & Japan & $2003-2006$ & FLD & Ultrasound & 21.8 & $46.4 \pm 8.9^{b}$ \\
\hline $\begin{array}{l}\text { Sookoian et al., } \\
2014\end{array}$ & Cross-section & Argentina & - & FLD & $\begin{array}{l}\text { Laboratory } \\
\text { examination } \\
\text { and biopsy }\end{array}$ & 29.82 & - \\
\hline $\begin{array}{l}\text { Hashimoto } \\
\text { et al.,2015 }\end{array}$ & $\begin{array}{l}\text { Retrospective } \\
\text { cohort }\end{array}$ & Japan & 1994-2003 & FLD & Ultrasound & 22.25 & - \\
\hline $\begin{array}{l}\text { Kächele et al., } \\
2015\end{array}$ & Cross-section & Germany & - & FLD & Ultrasound & 25.81 & $18-49$ \\
\hline $\begin{array}{l}\text { Moriya et al., } \\
2015\end{array}$ & $\begin{array}{l}\text { Cross-sectional } \\
\text { and } \\
\text { longitudinal }\end{array}$ & Japan & $2004-2006$ & FLD & Ultrasound & 23.04 & $\begin{array}{l}49.1 \pm 8.3^{a} \\
47.6 \pm 8.1^{b}\end{array}$ \\
\hline $\begin{array}{l}\text { Sogabe et al., } \\
2015\end{array}$ & Cross-section & Japan & $2008-2012$ & FLD & Ultrasound & 27.0 & $21-81^{a}$ \\
\hline $\begin{array}{l}\text { Lau et al., } \\
2015\end{array}$ & Cross-section & Germany & - & FLD & Ultrasound & 26.73 & $32-69$ \\
\hline $\begin{array}{l}\text { Nishioji et al., } \\
2015\end{array}$ & Cross-section & Japan & 2011-2012 & FLD & Ultrasound & $\begin{array}{l}27.32^{\mathrm{a}} \\
20.52^{\mathrm{b}}\end{array}$ & $22-92$ \\
\hline
\end{tabular}

aMale data; ${ }^{\mathrm{b} F e m a l e ~ d a t a ; ~ B M I, ~ b o d y ~ m a s s ~ i n d e x ; ~ F L D, ~ f a t t y ~ l i v e r ~ d i s e a s e . ~}$ 
Table 2. Summary of the results of studies included in the meta-analysis.

\begin{tabular}{|c|c|c|c|c|c|c|}
\hline \multirow[t]{2}{*}{ Study } & \multicolumn{3}{|c|}{ Male/ Female } & \multirow{2}{*}{$\begin{array}{l}\text { Alcohol } \\
\text { consumption }\end{array}$} & \multirow[t]{2}{*}{ OR $(95 \% \mathrm{Cl})$} & \multirow[t]{2}{*}{ Covariate adjustments } \\
\hline & $\begin{array}{l}\text { Non } \\
\text { drinkers }\end{array}$ & $\begin{array}{l}\text { LM } \\
\text { drinkers }\end{array}$ & $\begin{array}{l}\text { Heavy } \\
\text { drinkers }\end{array}$ & & & \\
\hline $\begin{array}{l}\text { Dunn } \\
\text { et al., } 2008\end{array}$ & $2553 / 4658$ & $2315 / 2228$ & $0 / 0$ & $\begin{array}{l}\text { Nondrinkers } \\
10 \text { g/day }\end{array}$ & $\begin{array}{l}1 \\
0.70(0.53,0.93)\end{array}$ & $\begin{array}{l}\text { Age, gender, race, income, } \\
\text { education, neighborhood } \\
\text { population density, caffeine } \\
\text { consumption, physical } \\
\text { activity }\end{array}$ \\
\hline $\begin{array}{l}\text { Cotrim } \\
\text { et al., } 2009\end{array}$ & $14 / 43$ & $27 / 48$ & $0 / 0$ & $\begin{array}{l}\text { Nondrinkers } \\
\leq 20 \mathrm{~g} / \text { day } \\
>20-40 \mathrm{~g} / \text { day }\end{array}$ & $\begin{array}{l}1 \\
0.98(0.30,3.24) \\
1.0(0.18,5.43)\end{array}$ & None \\
\hline $\begin{array}{l}\text { Gunji et al., } \\
2009\end{array}$ & $1706 / 0$ & $2879 / 0$ & $1014 / 0$ & $\begin{array}{l}\text { Nondrinkers } \\
40-140 \mathrm{~g} / \mathrm{week} \\
>140-280 \mathrm{~g} / \mathrm{week} \\
>280 \mathrm{~g} / \mathrm{week}\end{array}$ & $\begin{array}{l}1 \\
0.82(0.68,0.99)^{\mathrm{a}} \\
0.75(0.61,0.93)^{\mathrm{a}} \\
0.85(0.67,1.09)^{\mathrm{a}}\end{array}$ & $\begin{array}{l}\text { Age, body mass index, } \\
\text { waist girth, visceral adipose } \\
\text { tissue, subcutaneous } \\
\text { adipose tissues, systolic } \\
\text { blood pressure, diastolic } \\
\text { blood pressure, } \\
\text { high-density lipoprotein, } \\
\text { cholesterol, low-density } \\
\text { lipoprotein cholesterol, } \\
\text { triglycerides, fasting blood } \\
\text { glucose, glycated } \\
\text { hemoglobin, alanine } \\
\text { aminotransferase, smoking } \\
\text { status, dietary habits, } \\
\text { physical activity }\end{array}$ \\
\hline $\begin{array}{l}\text { Yamada } \\
\text { et al., } 2010\end{array}$ & $1040 / 3063$ & $3476 / 1857$ & $928 / 60$ & $\begin{array}{l}\text { Nondrinkers } \\
\text { Occasional } \\
\text { drinkers } \\
23 \mathrm{~g} / \text { day } \\
>46 \mathrm{~g} / \mathrm{day}\end{array}$ & $\begin{array}{l}1 \\
0.95(0.77,1.17)^{\mathrm{a}} \\
0.81(0.63,1.04)^{\mathrm{b}} \\
0.72(0.58,0.89)^{\mathrm{a}} \\
0.71(0.44,1.16)^{\mathrm{b}} \\
0.65(0.50,0.85)^{\mathrm{a}} \\
0.74(0.25,2.17)^{\mathrm{b}}\end{array}$ & $\begin{array}{l}\text { Age, body mass index, } \\
\text { smoking status }\end{array}$ \\
\hline $\begin{array}{l}\text { Hiramine } \\
\text { et al., } 2011\end{array}$ & $847 / 0$ & $4540 / 0$ & $347 / 0$ & $\begin{array}{l}\text { Nondrinkers } \\
<20 \text { g/day } \\
>60 \text { g/day }\end{array}$ & $\begin{array}{l}1 \\
0.71(0.59,0.86)^{\mathrm{a}} \\
0.44(0.32,0.62)^{\mathrm{a}}\end{array}$ & $\begin{array}{l}\text { Age, body mass index, } \\
\text { alanine aminotransferase, } \\
\text { aspartate } \\
\text { aminotransaminase, } \\
\gamma \text {-glutamyl transpeptidase, } \\
\text { triglycerides, high-density } \\
\text { lipoprotein }\end{array}$ \\
\hline $\begin{array}{l}\text { Wong } \\
\text { et al., } 2012\end{array}$ & $720^{c}$ & $148^{c}$ & $0^{c}$ & $\begin{array}{l}\text { Nondrinkers } \\
<10 \text { g/day }\end{array}$ & $\begin{array}{l}1 \\
1.37(0.89,2.11)\end{array}$ & $\begin{array}{l}\text { Demographic, metabolic } \\
\text { factors }\end{array}$ \\
\hline $\begin{array}{l}\text { Dunn et al., } \\
2012\end{array}$ & $70 / 181$ & $128 / 203$ & $0 / 0$ & $\begin{array}{l}\text { Non-drinks } \\
<20 \text { g/day }\end{array}$ & $\begin{array}{l}1 \\
0.56(0.39,0.84)\end{array}$ & $\begin{array}{l}\text { Gender, age, race, income, } \\
\text { education, glycated } \\
\text { hemoglobin, alanine } \\
\text { aminotransferase, } \\
\text { recreational, } \\
\text { non-recreational physical } \\
\text { activity, smoking, total } \\
\text { calories per day, percent } \\
\text { calories from } \\
\text { carbohydrates, percent } \\
\text { calories from fat }\end{array}$ \\
\hline
\end{tabular}


Hamaguchi

et al., 2012

Moriya

et al., 2013

$0 / 3403 \quad 0 / 1219$

/0 Nondrinkers

$<70 \mathrm{~g} /$ week

$70-139.9 \mathrm{~g} /$ week

$0.69(0.60,0.79)^{\mathrm{a}}$

$0.54(0.34,0.88)^{\mathrm{b}}$

$>140-280 \mathrm{~g} /$ week $\quad 0.72(0.63,0.83)^{\mathrm{a}}$

$0.43(0.21,0.88)^{\mathrm{b}}$

$>280 \mathrm{~g} /$ week

$0.74(0.64,0.85)^{\mathrm{a}}$

$1.02(0.44,2.35)^{b}$

1

$0.74(0.55,0.98)^{\mathrm{b}}$

$0.67(0.44,1.00)^{\mathrm{b}}$

Sookoian
et al., 2014

Hashimoto

et al., 2015

$1704 / 1765$

$1332 / 208$

$411 / 17$

$0 / 0$

Nondrinkers

$<40$ g/day

1

$0.49(0.30,0.79)$

Nondrinkers $\quad 1$

40-140 g/week $0.602(0.486,0.745)^{\mathrm{a}}$

$0.539(0.216,1.344)^{\mathrm{b}}$

$>140-280 \mathrm{~g} /$ week $\quad 0.607(0.484,0.763)^{\mathrm{a}}$

$0.366(0.050,2.680)^{\mathrm{b}}$

$>280 \mathrm{~g} /$ week $\quad 0.573(0.436,0.751)^{\mathrm{a}}$

$1.052(0.138,8.012)^{\mathrm{b}}$

1

$0.44(0.23,0.83)$

$0.96(0.53,1.71)$

$1.29(0.75,2.20)$

$>40$ g/day

$755 / 16$

Nondrinkers

$<70 \mathrm{~g} /$ week

1

70-139.9 g/week

$0.71(0.52,0.96)^{\mathrm{a}}$

$0.79(0.68,0.90)^{\mathrm{b}}$

$0.73(0.63,0.84)^{\mathrm{a}}$

$0.67(0.45,0.98)^{\mathrm{b}}$

$>140-280 \mathrm{~g} /$ week

$0.69(0.60,0.79)^{\mathrm{a}}$

$>280 \mathrm{~g} /$ week

$0.86(0.54,1.37)^{\mathrm{b}}$

$0.68(0.58,0.79)^{\mathrm{a}}$

$0.82(0.43,1.57)^{\mathrm{b}}$

$0 / 0$

$774 / 0$

Nondrinkers

drinking $<20$

g/day

1

$0.65(0.47,0.91)^{\mathrm{a}}$
Age, use of drugs.

metabolic syndrome,

regular exercise, smoking

Obesity, atherogenic, dyslipidemia, glucose intolerance, hyperuricemia, hypertension, current smoking status, age

None

None

Obesity, regular exercise, smoking

Age, body mass index, waist circumference, hypertension,

dyslipidaemia, uric acid, glycated hemoglobin, alanine aminotransferase, metabolic syndrome type

Age, body mass index, glycated hemoglobin, alanine aminotransferase, menopausal status in female 


\section{Conti iuarerJ}

\begin{tabular}{|c|c|c|c|c|c|c|}
\hline $\begin{array}{l}\text { Nishioji } \\
\text { et al., } 2015\end{array}$ & $165 / 1015$ & $175 / 574$ & $0 / 0$ & $\begin{array}{l}\text { Nondrinkers } \\
<20 \text { g/day }\end{array}$ & $\begin{array}{l}1 \\
0.49(0.27,0.90)^{\mathrm{a}} \\
0.66(0.44,0.99)^{\mathrm{b}}\end{array}$ & $\begin{array}{l}\text { Age, body fat percentage, } \\
\text { body mass index, waist } \\
\text { circumference, diastolic } \\
\text { blood pressure, total } \\
\text { protein, serum albumin, } \\
\text { alanine aminotransferase, } \\
\text { cholinesteras, triglycerides, } \\
\text { high-density lipoprotein, } \\
\text { glycated hemoglobin, blood } \\
\text { pressure risk }\end{array}$ \\
\hline
\end{tabular}

Manuscript to be reviewed

$0.49(0.27,0.90)^{\mathrm{a}}$

aMale data; ${ }^{\mathrm{b}}$ Female data; ${ }^{\mathrm{C}}$ Total number; LM drinkers, light to moderate drinkers; OR, odds ratio; $\mathrm{Cl}$, confidence interval. 
Table 3. Quality assessment of cross-sectional studies included in this meta- analysis.

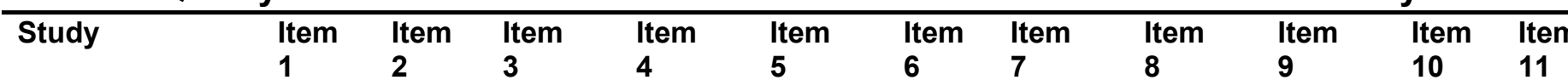

Dunn et al.

Y U

2008

Cotrim et al., $\quad Y \quad Y \quad Y \quad Y \quad Y$

2009

Gunji et al.

2009

Yamada et al.

2010

Hiramine et al.,

2011

Wong et al.,

2012

Dunn et al.

2012

Hamaguch

et al.,2012

Moriya et al.

2013

Sookoian et al.,

2014[24]

Kächele et al., $\quad \mathrm{Y} \quad \mathrm{Y}$

2015

Moriya et al.

2015

Sogabe et al.

2015

Lau et al.,

2015

Nishioji et al.

2015

Y, yes; N, no; U, unclear; Item 1, define the source of information (survey, record review); Item 2, list inclusion and exclusion criteria for exposed and unexposed subjects (cases and controls) or refer to previous publications; Item 3, indicate time period used for identifying patients; Item 4, indicate whether or not subjects were consecutive if not population-based; Item 5, indicate if evaluators of subjective components of study were masked to other aspects of the status of the participants; Item 6, describe any assessments undertaken for quality assurance purposes (e.g., test/retest of primary outcome measurements); Item 7, explain any patient exclusions from analysis; Item 8, describe how confounding was assessed and/or controlled; Item 9, if applicable, explain how missing data were handled in the analysis; Item 10, summarize patient response rates and completeness of data collection; Item 11, clarify what follow-up, if any, was expected and the percentage of patients for which incomplete data or follow-up was obtained. 
Records identified through database searching $(n=2847)$
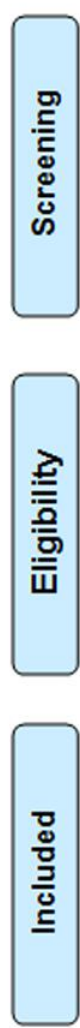

Additional records identified through other sources $(n=0)$

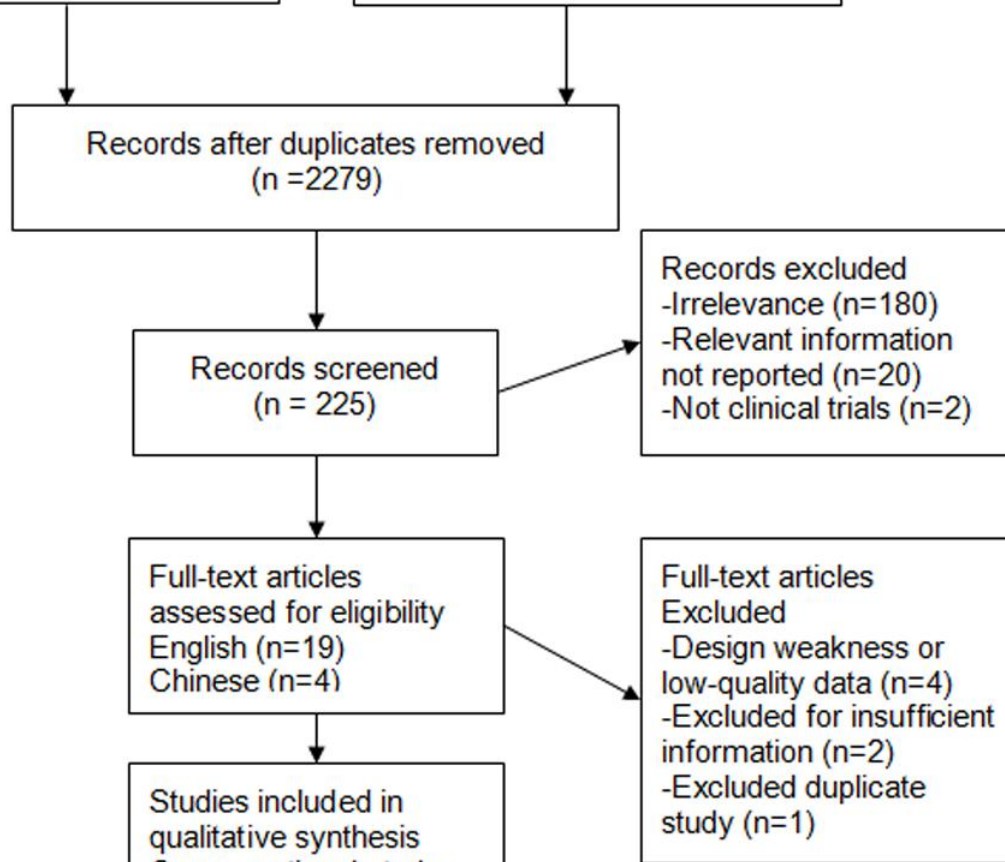

-sectional study

$(n=15)$

Cohort study $(n=1)$

Studies included in

quantitative synthesis

(meta-analysis)

English $(n=16)$

Figure 1: Search strategy and flow of information relative to the

meta-analysis. 
Study

$\%$

Weight

ID

OR $(95 \% \mathrm{Cl})$

$(\mathrm{D}+\mathrm{L})$

\begin{tabular}{|c|c|c|c|}
\hline \multicolumn{4}{|l|}{ LMAC } \\
\hline Dunn et al., 2008 & & $0.70(0.53,0.93)$ & 5.96 \\
\hline Cotrim et al., 2009 & & $0.99(0.32,3.02)$ & 0.85 \\
\hline Gunji et al., 2009 & & $0.79(0.69,0.91)$ & 8.60 \\
\hline Yamada et al., 2010 & & $0.82(0.72,0.92)$ & 8.86 \\
\hline Hiramine et al., 2011 & & $0.71(0.59,0.86)$ & 7.68 \\
\hline Wong et al., 2012 & $\infty$ & $1.37(0.89,2.11)$ & 3.85 \\
\hline Dunn et al., 2012 & & $0.56(0.39,0.84)$ & 4.42 \\
\hline Hamaguchi et al., 2012 & & $0.69(0.63,0.76)$ & 9.31 \\
\hline Moriya et al., 2013 & & $0.72(0.56,0.91)$ & 6.76 \\
\hline Sookoian et al., 2014 & & $0.49(0.30,0.79)$ & 3.28 \\
\hline Hashimoto et al., 2015 & 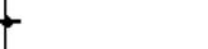 & $1.02(0.87,1.20)$ & 8.21 \\
\hline Kachele et al., 2015 & & $0.67(0.44,1.04)$ & 3.84 \\
\hline Moriya et al., 2015 & & $0.73(0.68,0.79)$ & 9.56 \\
\hline Sogabe et al., 2015 & & $0.65(0.47,0.91)$ & 5.25 \\
\hline Lau et al., 2015 & $\leftarrow$ & $1.19(1.03,1.38)$ & 8.50 \\
\hline Nishioji et al., 2015 & & $0.60(0.43,0.84)$ & 5.08 \\
\hline$D+L$ Subtotal $(1$-squared $=79.2 \%, p=0.000) \nabla$ & & $0.77(0.69,0.86)$ & 100.00 \\
\hline I-V Subtotal & & $0.78(0.75,0.81)$ & \\
\hline \multicolumn{4}{|l|}{ - } \\
\hline 1 & 1 & 1 & \\
\hline .01 & 10 & 100 & \\
\hline
\end{tabular}

Figure 2: Forest plot for assessing the association between light to moderate alcohol consumption and FLD. 
Study

$\%$

ID

OR $(95 \% \mathrm{Cl})$

Weight

Light alcohol consumption

Dunn et al., 2008

Cotrim et al., 2009

Gunji et al., 2009

Yamada et al., 2010

Hiramine et al., 2011

Wong et al., 2012

Dunn et al., 2012

Hamaguchi et al., 2012

Moriya et al., 2013

Hashimoto et al., 2015

Koachele et al., 2015

Moriya et al., 2015

Sogabe et al., 2015

Lau et al., 2015

Nishioji et al., 2015

$D+L$ Subtotal $($ I-squared $=66.0 \%, p=0.000) 0$

I-V Subtotal

$0.70(0.53,0.93)$

6.65

$0.98(0.30,3.24) \quad 0.73$

$0.82(0.68,0.99)$

9.01

$0.89(0.76,1.04) \quad 9.76$

$0.71(0.59,1.42) \quad 3.96$

$1.37(0.89,2.11) \quad 4.05$

$0.56(0.39,0.84) \quad 4.72$

$0.68(0.59,0.77) \quad 10.52$

$0.72(0.56,0.91) \quad 7.71$

$0.60(0.49,0.74) \quad 8.45$

$0.44(0.23,0.83) \quad 2.22$

$0.75(0.68,0.82) \quad 11.50$

$0.65(0.47,0.91) \quad 5.74$

$1.04(0.88,1.23) \quad 9.45$

$0.60(0.43,0.84) \quad 5.53$

$0.75(0.67,0.83) \quad 100.00$

$0.76(0.72,0.80)$

Moderate alcohol consumption

Yamada et al., 2010

Cotrim et al., 2009

Gunji et al., 2009

Hamaguchi et al., 2012

Hashimoto et al., 2015

Koachele et al., 2015

Moriya et al., 2015

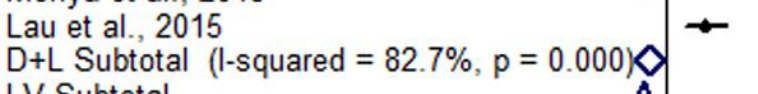

$0.72(0.59,0.87)$

15.32

$1.00(0.18,5.43) \quad 1.25$

$0.75(0.61,0.93) \quad 15.02$

$0.71(0.62,0.81) \quad 16.65$

$0.60(0.48,0.75) \quad 14.59$

$0.96(0.53,1.71) \quad 6.92$

$0.70(0.62,0.80) \quad 16.73$

$1.67(1.27,2.18) \quad 13.52$

$0.80(0.66,0.98) \quad 100.00$

I-V Subtotal

$0.75(0.70,0.80)$

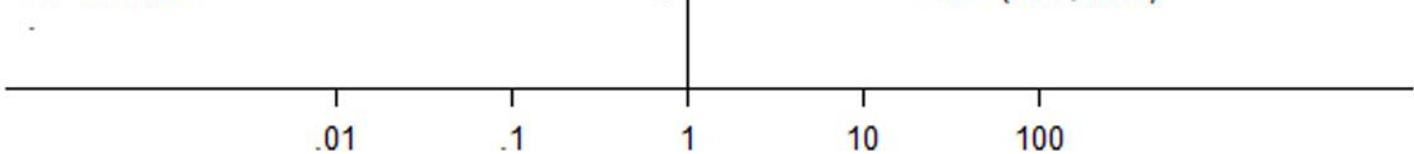

Figure 3: Forest plot for assessing the association between different amounts of alcohol consumption and FLD. 


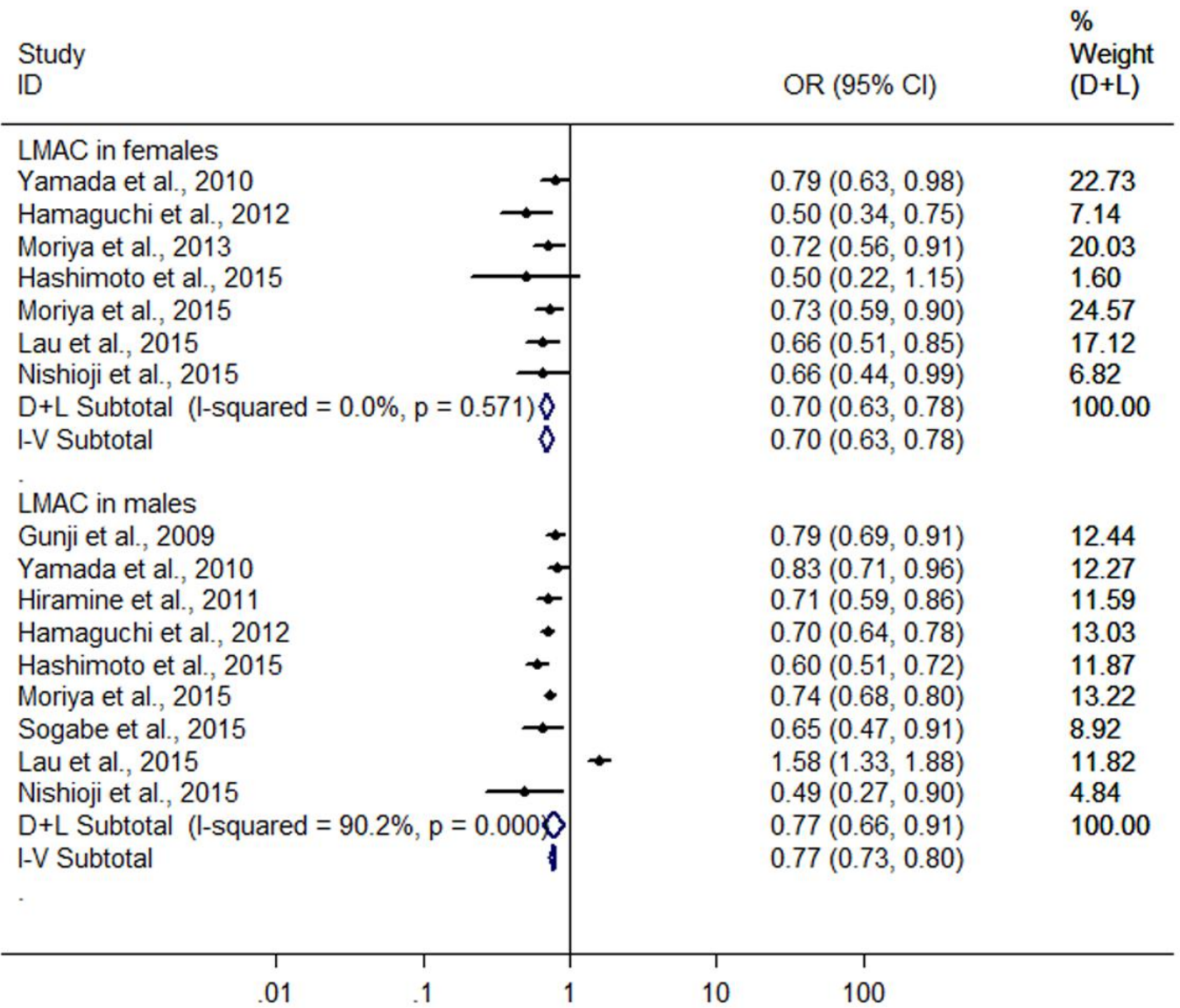

Figure 4: Forest plot of subgroup analysis conducted by sex for assessing the association between light to moderate alcohol consumption and FLD. 


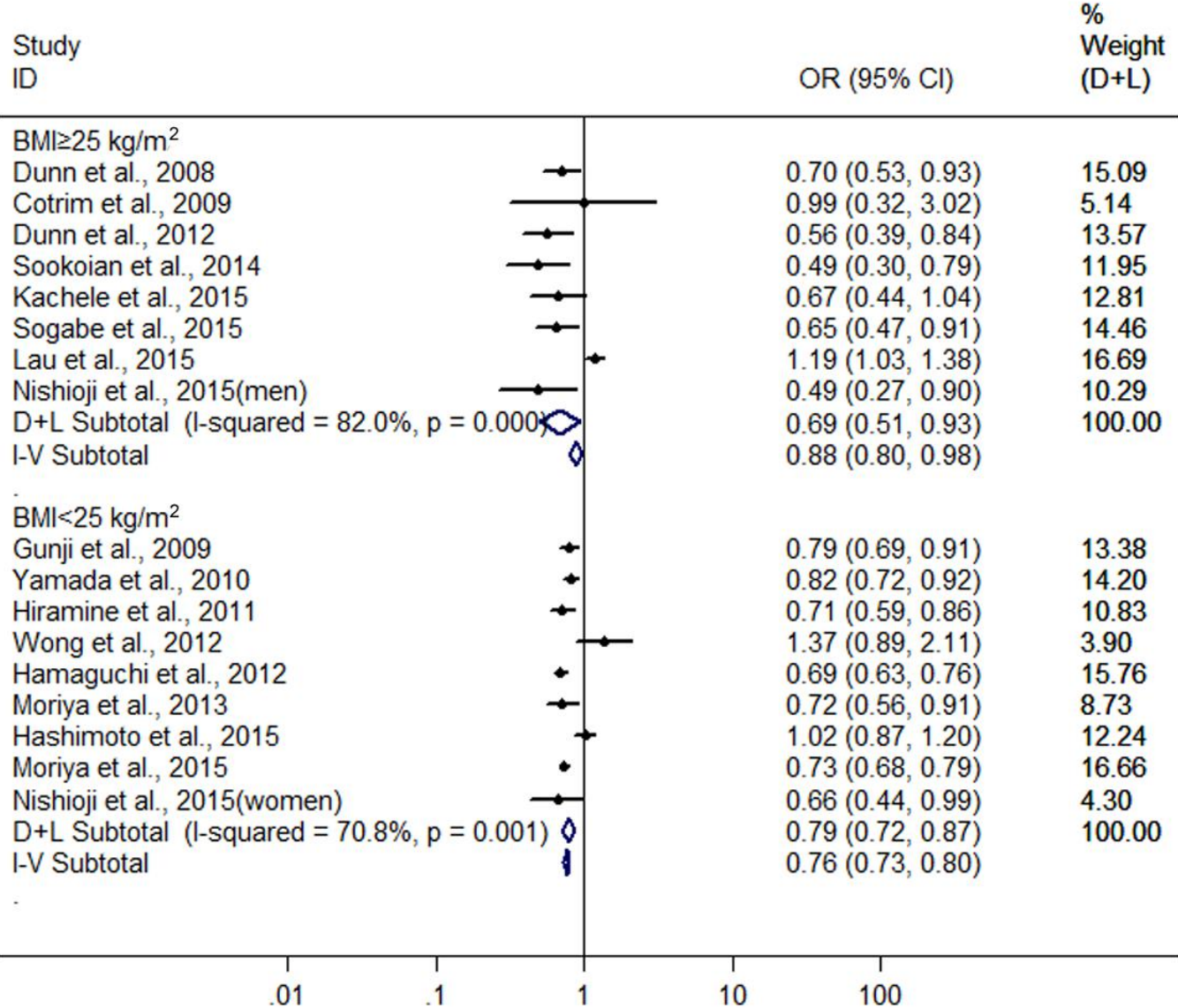

Figure 5: Forest plot of subgroup analysis conducted by BMI for assessing the association between light to moderate alcohol consumption and FLD. 


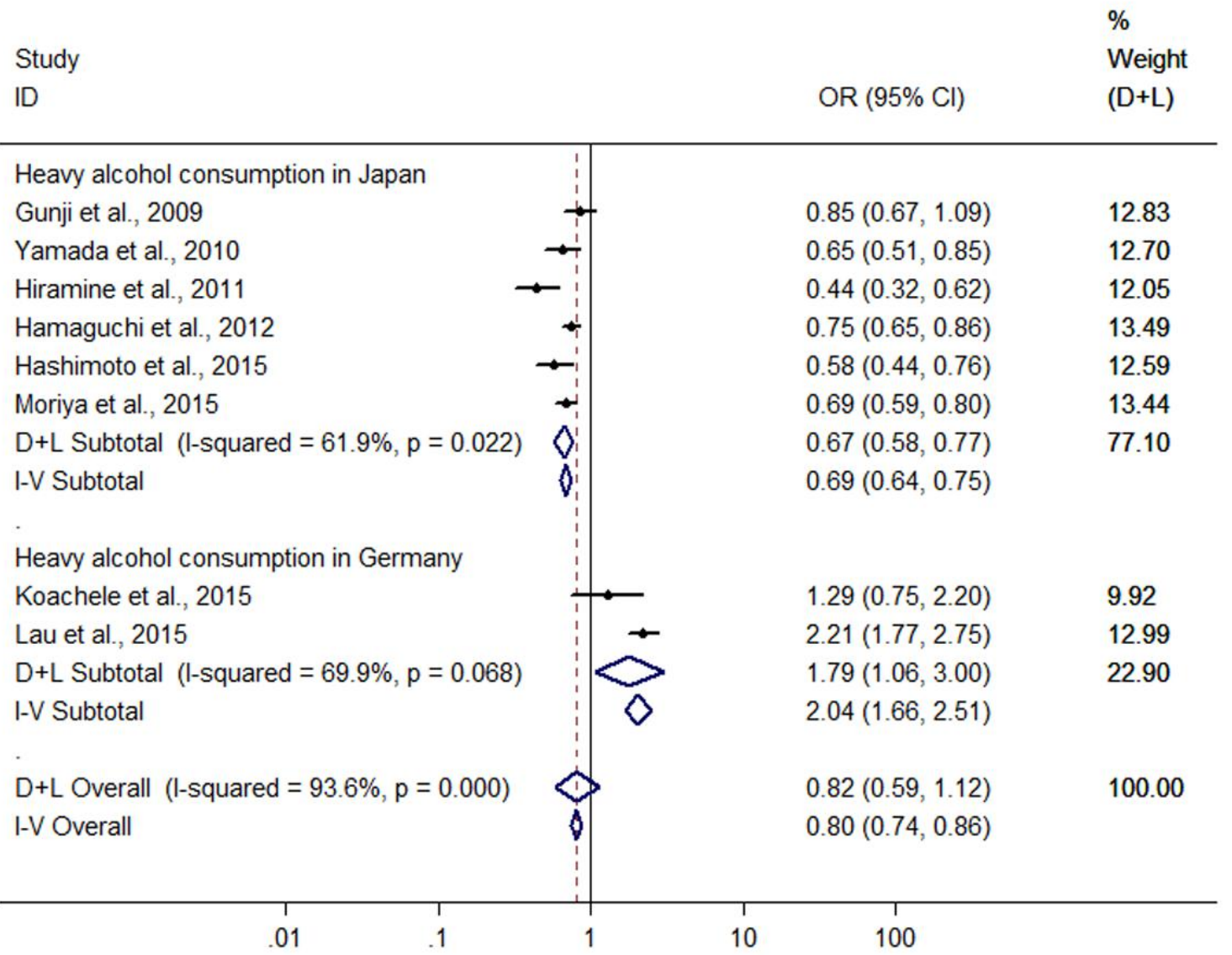

Figure 6: Forest plot for assessing the association between heavy alcohol consumption and FLD. 
Study

ID

Heavy alcohol in Japanese women

Yamada et al., 2010

Hamaguchi et al., 2012

Hashimoto et al., 2015

Moriya et al., 2015

I-V Subtotal (I-squared $=0.0 \%, p=0.962$ )

$\mathrm{D}+\mathrm{L}$ Subtotal

Heavy alcohol in Japanese men

Gunji et al., 2009

Yamada et al., 2010

Hiramine et al., 2011

Hamaguchi et al., 2012

Hashimoto et al., 2015

Moriya et al., 2015

I-V Subtotal (I-squared $=61.6 \%, p=0.023) 0$

$D+L$ Subtotal
$\%$

Weight

(I-V)

OR $(95 \% \mathrm{Cl})$

$0.74(0.25,2.17)$

17.45

$1.02(0.44,2.35)$

29.03

$1.05(0.14,8.01)$

4.94

$0.82(0.43,1.57)$

48.58

$0.87(0.55,1.36)$

100.00

$0.87(0.55,1.36)$

$0.85(0.67,1.09)$

11.82

$0.65(0.50,0.85)$

9.75

$0.44(0.32,0.62)$

6.28

$0.74(0.64,0.85)$

34.10

$0.57(0.44,0.75)$

9.29

$0.68(0.58,0.79)$

28.76

$0.69(0.63,0.74)$

100.00

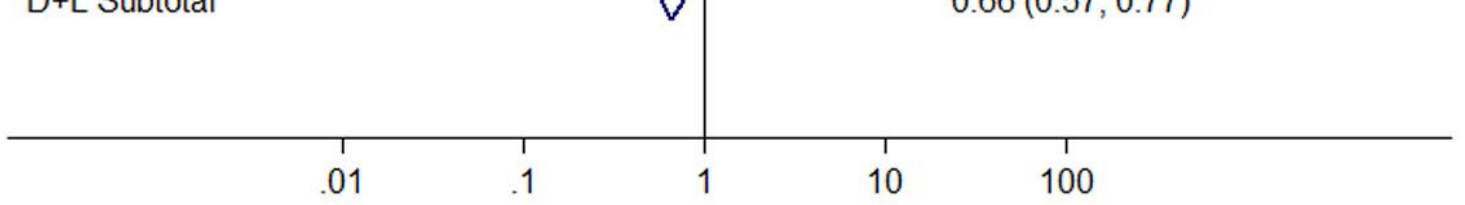

Figure 7: Forest plot of subgroup analysis conducted by sex for assessing the association between heavy alcohol consumption and FLD in Japan. 